\title{
The Possibility of Thinking on Existence: An Analysis Following the Traditions of Islamic Metaphysics*
}

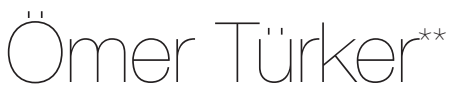

\begin{abstract}
With reference to Islamic intellectual traditions, this article seeks to demonstrate the possibility of speaking about existence qua existence, namely, the possibility of metaphysical knowledge. In fulfilling this aim, criticisms towards metaphysical knowledge are summarized in two main arguments, and then criticized. The first criticism is that metaphysical investigation transcends the limits of reason which is criticized in the article by answering the question of whether any kind of power including reason can transcend its limits. The second criticism is that concepts and propositions which are thought to be metaphysical are nothing but false perceptions (idräk). As a criticism of this argument, it is proposed that our knowledge of existence is indeed intuitional in the sense of being direct and non-instrumental, and that this intuition can be conceptualized by an analysis of everyday experience. In this context, with reference to "self-awareness", the article analyses the process of the transition of existence as a predication in the proposition of "I am" from ordinary conception of existence in the sense of being in the external world to the conception of universal existence which surround every thing in the external world and that is the very itself of being externally. It also sets forth the necessity and universality of the meaning of existence. Finally, the article seeks an answer to the question of how we can know that concepts and propositions which are achieved through a priori concepts, correspond to the external world.
\end{abstract}

Keywords: Metaphysics, Existence, Knowledge, Reason, Unity, Necessity.

* I would like thank İbrahim Halil Üçer, Abuzer Dişkaya, and Ayhan Çitil, who read the article and offered invaluable comments.

** Assoc. Prof., Marmara University, Faculty of Theology, Islamic Philosophy. 
For the face of a friend, left and right, on the lookout,

I was looking out, yet he was within, soul to soul

Niyāzĩ Mıṣrī

his essay seeks to demonstrate the possibility of thinking on existence following the theological, philosophical, and mystical traditions of Islam.

L I have to note in advance that the deep differences between the said traditions are irrelevant to my discussion, for I intend to state the legitimacy of metaphysics, not to discuss a particular problem within it. Occasionally, I prefer one tradition's view while criticizing another in order to utilize the potentials of the aforementioned traditions. For this purpose, I first touch upon what it means to speak of "being qua being" or investigating existence. Next, I establish that criticisms to claims of such an investigation derive from two false propositions: first, that reason has a transcendent quality in contradistinction with other mental faculties and second, that our metaphysical concepts are a result of such an inference. After a brief comment on the first proposition, I attempt to disprove the second by demonstrating that our ontic knowledge is essentially intuitional and that the conceptualization of intuition is achieved by the analysis of everyday experience. After this, I return to the first proposition and seek answers to the question of how we know that the concepts attained by reason correspond to the external world.

Any investigation of existence certainly relies on the knowability of the concept of existence by human reason. We attain our perception that there is something out there, or that the external is a receptacle to something, at least thanks to the language we have acquired. Human knowledge of either true percepts or scientific concepts and propositions is based on such an apprehension, for all our predications based on sound judgment or scientific study concerning an object are justified through its presence in the external world or in the mind..$^{1}$ Thus, there is no objection to a generic concept of existence, whether it precedes the senses or is abstracted from sensory perception. It therefore does not matter whether the concept of existence precedes sensory perception or not, because universality, meaning the attribution of a concept to many things, can account for universality as an expression of the externality of things. Then, all the words of a language require that the meaning in the mind be attributed to many things. This remains valid for the said meaning, whether held in common by individuals or differentiated across societies and even among individuals. As Quṭb al-Dīn al-Rāzī states, when we attribute a meaning in individual and collective memory to many things, that potential attribution is

1 What I mean by the word mind, in an extended sense, is the power of understanding, which comprises of both the internal and external senses as well as the apprehension of knowledge. See Sayyid Sharif al-Jurjānī, Al-Ta'rīfāt (İstanbul: Es‘ad Efendi Matba'ası, 1300/1883), art. "zihin." 
itself universality. ${ }^{2}$ But could we refer to a concept of existence independent of a specific being or a particular existence of external objects; universal insomuch as to be predicated to all objects in the world or in the mind? We could clarify the universality of the concept of existence in order to clarify the statement: Existence as a comprehensive and non-negligible meaning, that refers meanings actualized in all objects to itself, that maintains not the specific presence of objects but all such presences possible and meaningful, if neglected that our very being is neglected, once perceived that would enable the comprehension of the existence of all objects including our own being. In this sense, existence cannot be limited to the corporeal or the incorporeal in any way. For existence, whether corporeal or not, can be predicated to everything that exists, as long as it can be posited. The following question acquires significance right at this point: Is "being qua being" an achievable meaning? Since being qua being is the subject-matter of metaphysics among the classical branches of philosophy, we can ask whether metaphysical knowledge is possible.

Certainly, this question heralds a contradictory situation prima facie concerning the human subject in relation with its capacity for knowledge and being, because the human being is not the source of the meaning of existence, but rather a being actualized in the world. However, existence is thought of as a meaning that encompasses all objects that have existed and can exist. Thus, the human understanding of existence means the representation of the generic existence in the particular being's understanding, or the actualization of it, in the sense employed by the thinkers of the "unity of existence" doctrine. In turn, this requires the parallel extension of the particular being with that of the aforementioned sense. Therefore this proposition necessitates, contradictorily, an absolute aspect to a particular human being and the possibility of its identification with it, i.e. its universalization. Exactly for this reason, the possibility and objectivity of existential knowledge has been questioned by many thinkers, both past and present, who argued for its possibility and reality or denied such possibility to human knowledge. ${ }^{3}$ In the pre-modern era, criticisms of metaphysical knowledge, excluding the Sophists who denied all claims to knowledge, were founded upon the implausibility of the claims of knowledge for a field that appears entirely speculative even when our knowledge of the sensory world, considered to be immediate, was so lacking and uncertain, and the unreliability, fallaciousness, and relativity of reasoning. ${ }^{4}$

2 Quṭb al-Dīn al-Rāzī, "Risāla fī Taḥqīq al-Kulliyyāt" in Risāla fì Tahqĩa al-Kullīyyāt: Tümeller Risalesi ve Şerhleri, ed. and Turkish trans. Ömer Türker (İstanbul: Türkiye Yazma Eserler Kurumu Başkanlığ1, 2013), 20-22.

3 For instance, see Șadr al-Dīn al-Qūnawī, al-Murāsalāt bayna Ṣadr al-Dīn al-Qūnawī wa Nașīr al-Dīn alȚūsī, ed. Gudrun Schubert (Beyrut : Franz Steiner Verlag, 1995/1416), 51-60.

4 On this matter, see Fakhr al-Dīn al-Rāzī, al-Mațālib al-Āliya, ed. by Aḥmad Hijāzī al-Saqqā (Bairut: 
That is why metaphysician thinkers argued for the presence of a priori and selfevident (awwali and badīhì) knowledge of human reason that cannot be reduced to the senses, and that the reasoning based on it, supplemented by sensory data, led to metaphysical knowledge. Thus they busied themselves with showing the infallibility of the processes of reasoning. In addition, the prophetic traditions of the divine religions in the pre-modern era both provided a constructive critical function to the critique of the possibility of metaphysical knowledge and mended the defects of the disciplines with claims to universality, e.g. theology, mysticism, and metaphysics. Yet again, following religion's supportive role of the metaphysical tradition, such doubts and criticisms led to the prominence of mysticism in the later period of Islamic theology and philosophy (muta'akhkhirūn), because mystics claimed immediacy of the sort of sensory data for metaphysical knowledge, as it was in the experience of revelation. However, the critique of reason's claim to universal knowledge of existence gained impetus in the modern era with religion's losing ground, i.e. the loss of religion's support for reason and the development of the natural sciences. It can be suggested that these criticisms, commonly regarded as finding their most elaborate articulation in Kant, moved along two lines. The first one is expressed in the empiricist tradition: all human knowledge comes directly or indirectly from senses and there is no legitimate way to transcend the sensible existence. ${ }^{5}$ The second one is raised by Kant: all human capacity for knowledge has two bases; the innate categories of the mind (e.g. causality and so on) and sensory data. While categories make sensory data sensible, sensory data relieves categories from dullness and hollowness. There is no epistemological basis of humans' metaphysical transcendence, since the mind is part and parcel of the body. Kant argues that it is impossible to establish metaphysics as a science as long as the soul's existence and causality remain unproven. ${ }^{6}$ In short, the criticisms of the metaphysical understanding of the concept or proposition of "being qua being," whatever their reasons or forms of exposition were, postulate that what counted as metaphysical knowledge remained beyond the human capacity for knowledge, ergo, stood for delusion and fantasy. In my opinion, there is no difference between

Dār al-Kitāb al-'Arabī, 1987), I, 41-52, and al-Qūnawī, al-Murāsalāt, 39-55. For a detailed discussion including the sophist critique, see Sayyid Sharīf al-Jurjānī, Sharh al-Mawāqif: Mevâkıf Şerhi, ed. and Turkish trans. Ömer Türker (İstanbul: Türkiye Yazma Eserler Kurumu Başkanlığı, 2015), 1:214-78. The source of the debate for scholars contemporary with al-Āmidī, al-İjīi, al-Taftāzānī, and al-Jurjānī, is al-Rāzī's Muhașṣal. See Fakhr al-Dīn al-Rāzī, Muhașșal Afkār al-Mutaqaddimīn wa al-Muta'akhkhirīn min al-'Ulamā wa al-Hukamā' wa al-Mutakallimīn, ed. Tāhā 'Abd al-Ra'ūf (Cairo: Maktabat al-Kulliyyāt al-Azhariyyah, n.d.), 20-40.

5 For the empiricist critique, see Robert Audi, Epistemology, (New York: Routledge, 2005), 91-128.

6 Immanuel Kant, Prolegomena to Any Future Metaphysics, trans. Gary Hatfield (Cambridge: Cambridge University Press, 2004), 7-14; Immanuel Kant, Critique of Pure Reason, trans. Paul Guyer and Allen Wood (Cambridge: Cambridge University Press, 1998), 304-16. 
a straightforward expression of it and one that is mediated with other factors, as in Kant's moral metaphysics, where practical reason requires the existence of the soul and God in order to justify human freedom.

In the discussions of the possibility of metaphysical knowledge, thinkers who criticize metaphysics usually seek to determine where reason should stop or exceeded its own limits. We shall begin our discussion with the following question: Could any human faculty transcend its own limits? In other words, could we speak of the self-transcendence of any human faculty in a significant manner? One could also pose the question in particular to each faculty, whether internal (e.g., fantasia and estimation) or external (e.g., touch, taste, and hearing). The answer is obvious once one shifts the said faculties' domains of perception. For instance, it does not seem plausible that hearing could overtake taste or that touch could perform the task of hearing. While it is reasonable to assume that a faculty could be modified to serve another function by means of an external intervention, the character of the faculty in question would have been changed due to that condition, and the faculty of hearing would have merged with that of taste. Otherwise, a faculty cannot transcend its domain of perception. Reiterating the same question in reference to a shift in modes of being displays the problem more clearly: Is it possible for a corporeal capacity to perceive something incorporeal? The answer is almost self-evident: Certainly a capacity insofar as it remains corporeal cannot perceive anything incorporeal. This is why those who argue for the impossibility of metaphysical knowledge postulate that reason and the human mind have a corporeal capacity and, since this precludes them from perceiving something incorporeal, there is no legitimate reason to speak of any incorporeal being. ${ }^{7}$ If reason or mind are corporeal capacities, or if there is no possibility of an external intervention such as the one imagined that would extend the domain of perception for sensory apparatuses, then we should acknowledge the truth or at least the validity of this critique. Then, if a corporeal capacity or a bundle of capacities cannot perceive something incorporeal, could human individuals reach a conception of an incorporeal being? Some modern critics of metaphysics advocate silence on metaphysics, responding to the question in the negative because, having analyzed reason's inferential properties, they conclude that we could not arrive at metaphysics. In other words, our metaphysical concepts are just false percepts. It appears that this statement is based on two false assumptions: first, that reason, in contradistinction to other faculties, can transcend its limits of perception and second, that metaphysical concepts are inferred. 


\section{Two Assumptions of the Critics of Metaphysics}

\section{a. First Assumption: Reason Can Produce False Percepts}

This assumption, which strictly distinguishes reason from other faculties, is influenced by the traditional dualist approach that distinguishes the mode of existence perceived by reason from that perceived by the senses by making a variously strict or mild distinction which allows some interaction between the rational and the sensual. The critics of metaphysics were against it for good reason, but were caught at the pitfall of the dichotomy by means of discriminating the mode of reason's relation to its objects against those of other faculties and detached the act of knowing from others. However, the idea of the transcendence of knowing as a rational activity beyond the objects discernible by that faculty is a misstatement that arises out of relating the faculties to their objects, for reason, like other faculties, is encompassed by its own of objects of discernment and, eo ipso, could not have been involved with a mode of existence undiscerned in any way by it or that it recognized a being therein. This would be as nonsensical as saying that hearing could perceive taste without any transformation whatsoever. Unless human reason has the ability to sense a meaning unperceived by the sensory organs, it could neither discern nor express such a meaning. One of the more striking evidence for this is the human being's incapacity to envision any reason transcendent to its own. That is to say, humans cannot think of any being that possesses mental faculties with a different quality of knowing and thinking vis-à-vis mental content. True, humans can think of the concept of God, almighty and omniscient, but this godly cognition and perception forethought is distinguished from those of the human subject in terms of quantity rather than essence. Therefore, whatever we may call it, human reason can only perceive things within the domain of its own perception. In case it perceives something, that thing has to be present within its boundaries. We can formulate this into a syllogism:

a. A faculty cannot transcend its own percepts.

b. Reason is a mental faculty.

c. Therefore, reason cannot transcend its own percepts.

This syllogism enables us to distinguish between a percept's falsity and fallacy. It has to be noted that this statement is entirely independent of any percept's truth and falsity. When we say that the tongue can taste, we mean that everything perceived by it can be tasted, not that every taste perceived corresponds to its object. Likewise, when we mention the self-boundaries of reason we mean the impossibility of its "producing a false domain of perception" qua existence, not the "verity" of each and every concept and proposition. In other words, the falsity and fallacy of 
the perception are categorically different and attributing the first to a percept does not necessitate the second. While the truth or falsity of propositions is a question of correspondence, the truthfulness or fallacy has to do with the possibilities of knowledge. Thus, we may add the following to the categorical syllogism above:

a. Unless a faculty can transcend its self-boundaries, it cannot produce false percepts.

b. Reason cannot transcend itself.

c. Therefore, reason cannot produce false percepts.

Certainly, both syllogisms are silent on the reality of the meanings obtained by reason, whereas the critics of metaphysics aim right at this point, which is not subsumed by the syllogisms. Thus the demonstration, prima facie, appears to make no more than a verbal adjustment to the first assumption of the critics of metaphysics. That is to say, we can replace false percepts with incorrect percepts and the assumption still holds, because the assumption draws strength from the traditional metaphysics' dichotomy of the rational and the corporeal, or the corporeal and mental existence. Therefore, we have to question the validity of this dichotomy in order to elucidate the distinction between falsity and fallacy.

The classical philosophers of existence and knowledge, like Plato, Aristotle, Plotinus, al-Fārābī and Avicenna argued that percepts were differentiated by substance, since the sensory and the rational perceptions differed by mode. According to this line of reasoning, each faculty perceives a sphere of existence appropriate to itself, and the difference of faculties necessitates the difference of percepts. ${ }^{8}$ This reinforces the distinction of the hylomorphic theory devised by the philosophers of the various strands of the Peripatetic school who argued that physical objects are made of matter and form, whereas metaphysical objects are pure forms. In fact, a rigorous analysis would show that this distinction is questionable when applied to either the intellect and the senses or to physical/metaphysical objects. First, the relation of the intellect and the senses, as many Peripatetic philosophers argued, is not one of different capacities. ${ }^{9}$ On the contrary, the thinking subject, as some philosophers and theologians point out, is a single entity who employs multiple senses. In fact, it is the intellect that perceives and retains through the external senses (e.g., hearing, sight, and touch) and the internal senses (e.g., fantasia and 
estimation). But given that reason perceives only meanings, an object of perception presents itself to human understanding in the form of meaning. ${ }^{10}$ Hence, the dysfunction of any sense does not disable reason, whereas an inoperative intellect disables both reason and all sensory perception. This, in the first place, gives the impression, as argued by some Peripatetic philosophers, that external things are transformed by means of senses filtered through certain phases of abstraction into meaning. Rather than abstraction, the meaning already present in synthetic form outside is perceived via the senses and comprehended by reason in their individuality. In other words, external things are bundles of meanings, as opposed to something corporeal or incorporeal, and reason perceives their independent existence inasmuch as they are distinguished by means of instruments. External things are meanings and bundles of meanings, not only with regard to human perception but per se, because that which is perceived once a meaning is comprehended is not related to human disposition in the manner of an object that causes a particular perception of taste, smell, or color in the human body. Reason, while related to a particular body and temperament, is a capacity of perception that transcends them and makes an instrument of the affiliated body and temperament by turning them into an object of inquiry. Furthermore, the theory of hylomorphism itself is all too apt for an explication of what is dubbed 'matter' as a pile of condensed forms. According to the Peripatetic philosophers, hayūlā' (prima materia), at least through the stages of analysis, expresses a condition of sheer possibility and relative non-existence insofar as the form is yet to come. Matter comes into being with the arrival of the form. It does not make any difference that the prima materia never exists without form and that this formlessness is only realized in human perception, because this theory essentially presents the object as a pile of forms since it assumes that it will encounter a form at every instance in a process of infinite analysis. True, matter and form do not exist as independent meanings in any stage of the analysis; however, in contradistinction with the incorporeal Intellects in Peripatetic and Neo-Platonic philosophies, the meaning of matter is that of being the substrate for the form's actualization in corporeality. ${ }^{11}$

10 Ibn Sīnā, Al-Shifä’: Kitāb al-Nafs, eds. Jūrj Qanawātī and Sa îd Zāyid (Cairo: al-Hay'a al-Mișriyya al-'Āmy ma li-al-Kitāb, 1975), 163-221; Ibn Sīnā, Al-Ishārāt wa al-Tanbīhāt, ed. J.Forget (Leiden: E.J. Brill, 1892), 128-30. For a general assessment, see Fakhr al-Dīn al-Rāzī, Sharh al-Ishārāt wa al-Tanbīhāt (Istanbul: Dār al-Ṭibā'at al-Āmirah, 1290/1873), 239-40. Hereafter, this edition of the Sharh al-Ishärāt will be cited with the date of publication in order to distinguish it from Najafzādah (1383/1963) edition.

11 For an in depth analysis and comparison of the said hylomorphic theories of Neo-Platonic and Peripatetic philosophers with Avicenna see İbrahim Halil Üçer, İbn Sînâ Felsefesinde Suret, Cevher ve Varlik, (İstanbul: Klasik Yayınları, forthcoming title). 
Apparently, the concept of matter was included within the theory to support the explanation of the compound existence of forms, or in other parlance, generation and change. However, forms are meanings that we perceive due to the unity constituted by external objects. When we distinguish all of the essential attributes of an object in our analysis, we always come across another novel form or meaning. The forms per se, as the ultimate units of being, do not require any substrate or the coming together of the bundles they have formed. The Peripatetic thinkers also recognize that the substantial composition does not require an extra substrate. However, this recognition makes sense only if the existence of the prima materia as the ultimate substrate, as well as the secondary matter in any substantial composition, is certain. That is to say, the substantial composition does not require an extra substrate because it already contains it. With respect to meanings, however, form requires a subject that provides for its existence, unity, and composition, rather than a substrate. Just as artificial objects do not exist insofar as there is a human mind that produces and perceives them, the world of natural objects cannot exist unless there is a mind that produces and perceives them. In this context, the substrate for any present being, whether simple or complex, is the meaning of existence that provides for its presence. The sole exception to this is the meaning of existence itself. Thus there is nothing to perceive other than meaning, just as there are, in reality, no corporeal or incorporeal components to existence as a meaning that encompasses humans and all of the objects that exist.

The entire distinction of incorporeal and corporeal existence, as well as the nominal distinction concerning the simplicity and complexity of meanings, requires a different approach to the relation between human faculties and their objects. If the external world consists of only simple and compound meanings, then not only reason, but also the external and internal senses can perceive these meanings. In that case, two aspects distinguish the rational faculty: First, human reason is aware of its perception, as distinct from the integral meanings of other living beings that possess the capacity for perception. Second, it is not limited to a particular mode of existence, like that of being visible, audible, tangible, or gustable. Since the supplementary faculty of the human subject is reason, all faculties can be used by humans as gateways to their semantic universe. Then, the objects of reason as the sole faculty that can perceive meanings with awareness are equal to the wide array of the manifestations of the meaning of existence. That is to say, the field of rational perception is identical to the field of determinations of the meaning of existence; and if a thing is intelligible, it must exist, and vice versa. As treated more extensively below, this indicates not that the meaning of existence or its infinite manifestations can be exhausted by the human mind, but that they cannot exist unless they are based on an absolute mind with an awareness like that of the human 
mind, since an unknown meaning cannot exist. We can formulate the argument into the following syllogism:

a. Everything that exists is a meaning.

b. All meaning is within reason's field of perception.

c. Therefore, everything that exists is within reason's field of perception.

This syllogism shows us that it is not possible to speak of reason's transcendence of boundaries and fallacy in its perceptions. However, it says nothing about the verity or reality of the meanings achieved by reason because the question of truth and correspondence can only be resolved by analyzing the formative process of the meaning of existence or of other metaphysical concepts and propositions present in our mind. Subsequently, we have to turn to the second assumption of the critics of metaphysics: that metaphysical concepts like existence, unity, and infinity are inferential, in order to tackle the question of correspondence.

\section{b. Second Assumption: The Knowledge of Existence Is Inferential}

According to this assumption, our perception of the meaning of existence is achieved by reasoning. But reasoning can never justify a perception concerning the whole. Yet metaphysics emerges through a deep analysis of everyday experience, by which we are able to discriminate between 'existence', in the sense of an object's external being and 'universal existence' which comes into being by encompassing all objects. It also makes it possible for us to acquire the concept of existence. Thus the basic question to be posed at this point is how everyday experience evolves into metaphysical comprehension.

Metaphysics is based on the self-evidence of the concept of existence. This supposedly self-evident concept means that the external is a receptacle for something, or that being is realized outside. In this sense, the concept of existence is a priori, that is, it precedes all of our concepts. As Fakhr al-Dīn al-Rāzì stated, to be quoted below, once humans acquire self-awareness they achieve an awareness concerning both their own existence and that of other objects. That is, the pronoun "I" refers to the realization not of a single thing outside, but rather of multiple things outside. The importance of this awareness is that an object's existence has a core from which all the meanings that characterize its external being can be inferred. In this context, an object's existence is its final meaning, which it presents to our perception. Thus the knowledge of existence covers the entire spectrum between the object's external realization and its final meaning, which manifests in our perception. The key point in the transition from the realization to the object's 
final meaning is the accompaniment of the perceiving subject's self-awareness to all of the processes of construction. The connection between human existence and the general knowledge of existence, established by Mu'ammar ibn 'Abbād al-Sulamī, Avicenna, Fakhr al-Dīn al-Rāzī, and Șadr al-Dīn al-Qūnawī among the Islamic thinkers, is quite striking at showing that metaphysics is a realization that evolves into individual existence. The passage that al-Jāhiz extracted from Mu'ammar Ibn 'Abbād al-Sulamī is very similar to that of Avicenna's "floating man":

Prior to all these comes man's knowledge concerning itself. Mu'ammar renders it primary to all knowledge and prior to sensory perception. He said: 'Human's knowledge of itself should be prioritized to its knowledge of other things.' He considered this knowledge as extraneous to sensory perception, because a human being would not sense his voice if deaf but senses itself; would not sense smell if it were unable to smell, but could absolutely sense itself. It also applies to the circumstances of taste and touch. Therefore this knowledge should be distinguished from sensory perception and rendered the eighth domain of knowledge in and of itself. ${ }^{12}$

Mu'ammar, in contrast to earlier theologians, defends the thesis that the soul is an incorporeal substance. Congruous with this opinion, this passage is based on the postulate that the human substance preceded all of its actions and instruments. Since the substance exists as a knowing subject, its existence and the knowledge of existence are two sides of the same coin. Avicenna's famous "floating man" argument expresses more conspicuously the non-negligibility of the awareness of existence and the self for humans:

Imagine someone to be created perfectly at an instance. But let him not see the things outside. He shall rest suspended in air or in vacuum. He would not be exposed to any air flow that may be sensed. His organs would be spread and not connected with each other in any way. Then he shall think whether the existence of himself is real and not doubt that he himself exists. Meanwhile, he shall affirm none of his internal and external organs, neither his heart nor his brain, nor any other external thing. On the contrary, he shall affirm only himself and not attribute any length, width, or depth to it. In this state, the possibility of his imagining a hand or any other organ notwithstanding, he will not imagine it as a part and parcel or a condition of himself. ${ }^{13}$

This passage emphasizes the insignificance of temporality or of being constituted in time in the scale of human knowledge, with respect to the knowledge of existence, in a rather striking manner. Avicenna's preference for an adult rather than an

12 Al-Jāhiz recounts this view in the treatment of Mu'ammar's assortment of knowledge into ten kinds. see Abū 'Uthmān 'Amr ibn Baḥr al-Jāhiẓ, "Al-Masā’il wa-al-Jawābāt fī al-Ma'rifah,” in Rasā’il al-Jāhiẓ, ed. 'Abd al-Salām Muhammad Hārūn (Cairo: Maktabat al-Khānjī, 1979), 4:51-52. 
infant indicates that the thought experiment is not hypothetical, because our selfawareness precedes all our faculties and perceptions at one particular moment or at any moment when we can think of our existence. Unless a thing exists per se, it cannot be in situ. Since the most special quality of a human is to know, being human is identical to being rational at the same time. That is to say, a rational being, rather than being a human attribute, is an essential predicate that was contained within the sense of existence actualized in human being and, therefore, necessarily predicated when we say "human beings exist." In this regard, Avicenna's experiment is a new expression of the ancient view that holds knowing to be an essential predicate rather than an essential accident (al-'arad al-dhātì/proprium) for a human being. For this reason, it neglects the formation of concepts and propositions through time, because it makes a sharp distinction between the temporality of being and the eternity of the particular being qua particular existence. Certainly, the said eternity is based on the impossibility of his existence being subject to time while he is within time. In other parlance, we comprehend any person only as a meaning that exists when considered independent of secondary qualities, because in that case he is not in a state of becoming, does not pass over to another category, and is not subject to any sort of motion including that of substance. As a matter of fact, this state of affairs is not confined to human existence, for it circumscribes all beings and posits itself as the primary mode of all particulars. Therefore everything that exists remains as a meaning entirely independent of the process of becoming at the level of substance and accident. It would have been impossible to speak of the existence of any particular being if there had not been such a constant. Following right from this point, Fakhr al-Dīn al-Rāzì quite rightly arrived at the analogy between the human's self-awareness and its perception of existence. Although later thinkers like al-Kātibī, al-Tūsī, al-Ījī, al-Taftāzānī, and Sayyid Sharīf al-Jurjānī criticized alRāzì on the grounds that he did not distinguish between the occurrence and the perception of existence, ${ }^{14}$ his point was the identity between the particularity and the existence of a human being. Notwithstanding the fact that this applies not only to human beings but to all objects, as stated right away, the reason why the train of thought departs from a human being is that to know is a predicate that defines a human being, as distinct from other objects. Furthermore, there is no necessary perfect correspondence in the hierarchy between the formative process of the knowledge of concepts and propositions and the existence and states evinced by these concepts and propositions, insofar as we presume a human being to be a knowing subject. That is to say, even if we were to arrive at the concept of existence after acquiring quite a bit of knowledge, the inevitable precedence of existence 
would not be compromised. We can say this because we would be convinced that the basis of all our knowledge is the knowledge of existence and that it should take precedence, and because we would set the perception of existence we acquired not at the tail end of other perceptions but at the base, in such a case. In this vein, alRāzī says in al-Mabāhith al-Mashriqīya:

The knowledge of a human being of his existence is not acquired; existence is part and parcel of his being. Knowing the part precedes knowing the whole. Thus, human being's knowledge of existence precedes the knowledge of his being. It is proper for what precedes the unacquired that it be unacquired. If it is asked: "Why does a human being not acquire the knowledge of the existence of itself?" we would say that the falsity of it would be displayed in the section about the soul. Even if we concede this point, it would not falsify what we meant, because we cannot infer the existence of the conclusion unless we know of the existence of the premise. To know the existence of every premise does not require further premises, for a vicious circle and an infinite regression of premises is impossible. Therefore, it should come to a rest wherewithal its existence is self-evident. [...] Ergo the conception of existence is a priori. ${ }^{15}$

In this passage, al-Rāzì points out that the knowledge of existence was subsumed by the knowledge of the self and that it was the precedent to all other knowledge, even though he did not mention, in fact, that existence is not a predicate to the self in the proposition "I am." This is because the "I," as an expression referring to one's person, cannot be spelled out by a subject that does not perceive itself. Therefore, the pronoun "I" of the knowing subject inevitably involves his comprehension of being. Even though al-Rāzì writes that the self is to existence what the part is to whole, this has to be a reference to the layers recognized by means of attributing a single perception to many things. For that reason, he argues that the knowledge of self, like the knowledge of existence, is not acquired and that, in case the knowledge of the self is presumed to be acquired, it would be the comprehensive priority of existence. In other words, while the perception of the self and of existence is one and the same, considering the particularity of the self and the universality of existence in the process of constructing knowledge, it would be concluded that the existence in the perception of the self is a particular actualization of a universal concept of existence. As will be mentioned in further details below within the context of Sadr al-Dīn al-Qūnawì's commentary on the passages, the universality of the perception of existence and the particularity of the perception of the self attest not to two perceptions out there, but to two sides of a single perception. That is, it is a single perception à la person, different à la notion. On the one hand, inasmuch as the 
universality of existence is perceived, the perception of the self is perceived; on the other hand, in terms of the particularity of the latter vis-à-vis the former, the totality of both are perceived together. Therefore, there is a sort of identity between the perceptions of the self and of existence, rather than what is particular to what is universal. For this reason, the more salient the perception of existence becomes, the more the perception of the self becomes in tandem. This holds with respect to both the categorical properties of the objects that the self was dissociated into and the quantitative multiplicity of the objects. That is, the growing salience of the perception of existence adds to the extent of the identity with the self as well as the extent of dissociation formed by awareness.

The key point at the growing extent seems to be the process of the predication of existence evolving from existence qua "being external" (al-wujūd al-'amm) to the "external being" (mawjūd). Almost all of the objections to the possibility of metaphysical knowledge originate from erroneous analyses of omission or commission in terms of this process. The diversity of human knowledge gives the impression of an evolving meaning of existence growing from quantity to quality. In fact, we perceive various forms of existence qua external being as long as we comprehend the diversity and the depth of the world of objects. The import of the contemporary sciences, with respect to the physical and mathematical aspects of the objects, is that we became more deeply conscious of just how incomplete our knowledge concerning the features and various purports of the reification of the meaning of existence, or gaining its current sense, really is. Notwithstanding this state of affairs, which is taken to be counter-evidence to the conception of classical metaphysics, metaphysics as a discipline, historically speaking, never derived its reason for being or legitimacy from the particular sciences. The meaning of existence that was intuitionally conceived cannot be derived from external beings, for it was not inferentially acquired. That is why it is not susceptible to refutation with the ignorance of the qualities of each and every object. Hence Avicenna, who established metaphysics as a science in the Islamic world, made striking observations concerning the essences investigated by the particular sciences:

We know of things only by their attributes, concomitants, and accidents. We do not know of the differentia that posits every single thing and attests to its essence. On the contrary, we know that they are things with a number of properties and attributes. As we do not know the essence of the First, reason, soul, cosmos, fire, air, water, and earth, so we do not know the essences of the attributes. The only thing we know is that there is a thing possessing such a quality and that it is not predicated of a subject. However, this is not its essence. Neither do we know the essence of body (al-jism). On the contrary, it is a substrate possessing these properties, that is to say, the qualities of length, width, and depth. Neither do we know the essence of the animate. What we do know is that it is 
a substrate that has the properties of perception and action. However, these are not the essence of the animate being. We do not know the real differentia. For this reason the qualities of things were contested, because everyone perceived a requisite that the others did not and judged accordingly. Once we identify something, we know that it possesses a property or properties. Thereupon we know that it possessed other properties by means of what we knew. Then we know its haecceity (anniya). For instance, it applies to the soul, space, etc. We know their existence not by their particularity, but with respect to the things we know or by an accident or a concomitant that they possess. ${ }^{16}$

One can come across similar sentences by Avicenna in his al-Mubāhathāt as well. Even more, one can catch comments that may read along the same line with this passage in between the lines of his al-Shifá ' corpus, which he wrote according to the traditional classifications and arrangement. ${ }^{17}$ Notwithstanding other passages showing that metaphysics provides the principles for the particular sciences, this and similar passages indicate the frailty of the essences studied by the particular sciences so that they will not form a basis for the more encompassing and rational meaning of existence. Therefore, Avicenna did not mean to say that our perception of the states of being qua being was susceptible to our ignorance concerning the essences of species, because our knowledge of the meaning of existence concerning its origin and the universal states of its external being does not depend on the essence of the species of water, body, or another thing. On the contrary, the existential value of the essence of the species of the aforementioned set is preceded by our comprehension of the universal states of the meaning of existence. Moreover, Șadr al-Dīn al-Qūnawī, who sought to establish mysticism as a universal discipline, cited the first lines of the passage by Avicenna, "to grasp the essence of things exceeds human capacity. The ultimate thing a human being can know is the attributes, concomitants, and accidents of things" in one of the letters discussing the possibility of metaphysical knowledge that he addressed to Nașir al-Dīn Tūsī, ${ }^{18}$ in which he analyzed it in the context of theoretical reason's capacity to comprehend existence. Al-Qūnawì's analysis emphasizes the limits of intellectual capacity and that essences are only perceived by means of the absolute aspect or the particular aspect toward God, whereby human beings comprehend the absoluteness of existence. These analyses, prima facie, put forth the supposition that the essences that Avicenna dubbed "incomprehensible" could be perceived by a faculty other than one's intellectual capacity. However, a rigorous analysis indicates that this was not the case at all. Al-Qūnawì does not mention an essence of

16 Ibn Sīnā, al-Ta'līqāt, ed. 'Abd al-Raḥmān Badawī (Qom: Maktabat al-I'lām al-Islāmī, 1984), 34-35.

17 For the relevant passages with extended commentary, see Türker, İbn Sînâ Felsefesinde Metafizik Bilginin İmkânı Sorunu, 133-67.

18 al-Qūnawī, al-Murāsalāt, 51. 
water, body, soul, or space that can be comprehended through a kind of witnessing (mushāhada) other than what is already known, neither in his al-Murāselāt or his I'cāz al-Bayān fì Tafsìr al-Qur'ān, where he made this and similar analyses, nor in his works like Miftāḥ al-Ghayb and al-Nuṣūṣ, in which he sought to establish mysticism as a metaphysical discipline. That is, whereas the scientific legacy inherited by alQunawi dictated " $\mathrm{A}$ " for the essence of water and body, it is not the case that he postulated " $\mathrm{B}$ " for the same essence achieved by another capacity of human soul or another method. Instead, by means of evaluating the levels of being with respect to the ultimate meaning of existence, al-Qunawi analyzes the position and relation of the said levels according to whether the propositions of existence and possibility are valid or not. In other words, he investigates the relation of the levels of being to absolute existence and, in this context, how the meaning of existence was realized at different levels. While this investigation is remarkably different from the metaphysics of Avicenna or al-Rāzī in terms of method and problematics, it does follow a common thread by pursuing the perception of the effects of existence and possibility in a deductive manner.

\section{Two Aspects of Metaphysical Comprehension}

\section{a. The transition from existence to being}

If the perception of existence precedes the perception of beings, how could we move on to a knowledge of beings as the actualized forms of existence? Thus, the relevant question at this point is what enables our perception of all forms of existence. The answer lies in the human capacity to perceive both the existence of itself and the existence of other objects. This quality breeds in human beings a constant curiosity and attention toward all objects outside itself. In this context, the human mind rests in a state of continuous attention toward all of the things that surround it. Having analyzed this characteristic more strictly, what appeared prima facie to distinguish human beings is observed in all beings dependent on its own features of existence. And so al-Qūnawī says: "In all things, there is an absolute aspect toward God and a limited aspect (taqyìd)," ${ }^{19}$ because, as Avicennan understanding of essences indicates, to exist necessitates to partake of the absoluteness of existence on the one hand, and to be limited by realization on the other. In this context, there is no object in the known world oblivious to its own existence, and no object impervious to the existence of other objects insofar as they are related to its own 
existence. That is, the attention of every object is determined by the measure of potentials or limits à la al-Qūnawī, which makes a certain quantity of the extent of its existence. A human being differs from other objects in that its curiosity and attention is not bound by its proximate environment or a certain set of beings, due to the infinity of the rational faculty as the capacity of perceiving meanings. It allows the absoluteness of the human being's extent to evolve into a conscious absoluteness, as distinct from that of other objects. That is, the capacity to reason and to know is the supreme capacity that the absoluteness of existence itself disclosed, and just as a necessary conclusion of this capacity to reason and to know, a human being arrives at a concept of existence that can be predicated to all objects, as well as a language that approximates its objects by means of universal concepts. Probably this is why al-Rāzì examined the knowledge of the self and of existence at the same frame. In this context, one should not miss that the capacity to reason and to know is in a state of constant desire of its own objects, just like in every other capacity. Knowing, as a definitive human trait as well as an aptitude that secures human wholesomeness, makes up for both the motive, as al-Rāzī pointed out, and the objective for its predisposition to wholeness with its objects. For this reason, all human capacities essentially serve the capacity of reasoning and exist inasmuch as they can, for once these capacities are cut off from reasoning, the capacity for desire and anger stops being human. Therefore, the capacity of reasoning, on the on hand, resides at the base of all capacities and, on the other hand, is supreme. Moreover, while each serves its own function, by the same token it also serves an extension of reasoning. This state certainly shows that the perception of existence and the self, as Avicenna and al-Rāzī suggested, were both at the base of all knowledge and perceptions and the objective of all perceptions. That is, any perception originates from and returns to the rational faculty. Thus, human existence resembles a bundle of faculties among which knowing or reasoning is supreme.

If there is a faculty, certainly there is a mode of existence that is perceived by it, because faculties are reciprocal with their functions. That is, any capacity exists in and of a subject, as it bears them. For instance, sight or hearing is specifically actualized with objects subject to its perception. Likewise, the fact that those objects are visible and audible is actualized through the faculties that perceives them. Thus both reasoning and, accordingly, other faculties desire and necessitate their own objects, and the percepts subject to perception necessitate a faculty or subject that perceives them. Therefore, it is not only meaningless but also impossible to speak of sight without that which is seen, taste without that which is tasted, reason without that which is known, and vice versa. This indicates the coexistence of the perception of the self with the perception of other beings. In other words, any perception is realized by the comprehension of the individuality 
of things that are, and the faculty cannot conceive of its own individuality insofar as it did not conceive of the individuality of an external being, except for itself. Thus the shift from concept to proposition concerning the human being's perception of its own existence inevitably materializes when it perceives other objects. Yet, this is a sum total of perceptions that involves priority-posteriority among them visà-vis existence, rather than a totality of temporally ordered perceptions, at least initially. Certainly, unless a thing exists in itself, it cannot bear other attributes and actions. Therefore, the existence of a human being as a perceiving subject precedes all phases of perception. But awareness in the form of a proposition concerning the self is a reciprocal one, for it is both realized and expanded by perceiving other individualities. What must not to be missed here is the contradictory incorporation of both individuality and universality within the same perception, for the particular cannot actualize without the universal. There is no thing but the particular being; no water but the body; no sweet, salty, bitter water but the water. Thus, once an individual external being is perceived, by the same token a semantic continuum, varying from particular to universal, is conceived. If this had not been the case, it would have been impossible for a human being to make general predications and to produce a language consisting of universal meanings. Concurrently, both the generality of meanings and the mutuality of them among various objects, as well as their particularity and uniqueness, are conceived by reason; however, the object lends the meaning to the subject that perceives itself via various faculties. In other words, just as the perceiving subject's comprehension of its own unity is a gift, so is its comprehension of the unity of the object that is subject to its perception. The perception of unity does not require acquisition, as does the perception of existence, because it is impossible to comprehend an object's existence without comprehending its unity, or vice versa. Moreover, the perception of unity reciprocally necessitates the perception of alterity. The leap that transforms this bundle of perceptions from everyday experience to scientific awareness is taken when one comprehends the meanings of existence, unity, and alterity in the first place, and that they can be both particular and universal. That is, reason thinks of a certain object that exists, is single, and distinct on the one hand, and of the meanings of existence, unity, and difference present in all objects that it perceived and can perceive on the other. By the same token, reason obtains the possibility of comprehending existence and unity as general predicates along with the existence and unity particular to a certain object. Thus, reason arrives at the thought of "being qua being" as it moves from the part to the whole and turns this transition into awareness.

\section{b. The transition from being to existence}


The transition from the part to the whole is intuitional in the sense that it is instantaneous. That is to say, the perceiving subject becomes aware of the appearance of the meaning in parts in relation to the whole to be the whole itself, thanks to the repetition of experience. For this reason, the said intuition is the state of a succinct perception whereby the unity and comprehensiveness of meaning is instantaneously conceived of by the perceiving subject, so that the totalizing and universalizing attribute of reason is salient and immediate to the greatest degree in the perception of the universalization of the perception of existence and unity. Therefore, what I mean by intuitionality is not the intuitions accompanied by latent analogies. Such an intuition, as Sayyid Sharîf al-Jurjānī suggested, contains as many syllogisms as the number of causes:

There has to be repetition of sensory perceptions and additionally latent syllogisms in intuitionals, as in empiricals. The difference between the intuitionals and empiricals is this: In empiricals, the causality of the cause is known, but its essence is not. That's why the syllogism with them is single. That syllogism is as follows: It would not be, always or almost, unless by a cause. In intuitionals, however, both the causality and the essence of the cause are known. Therefore, there could be as many syllogisms accompanying them as the number of different causes in the essence of causes. ${ }^{20}$

Intuition, in the sense employed in this passage, is not appropriate for explaining the perception of existence and unity. True, reason can neither universalize the perception of its own existence nor comprehend that this perception contains the perception of the whole at the same time, lest the repetition of sensory perception. Yet no middle term exists that can be used to indicate that reason has arrived at the whole once sensory perception is realized. That is, a disclosure concerning the whole occurs in the perceiving subject once it is admonished, for the pile of perceptions serves the function of admonition (tanbihh), but not of means, at that instance. It is like the eye that sees what is in its line of sight. Someone looking at something sees everything in his line of sight, but neglects the others once it specifically orients itself toward just one sight. It minds the thing or things that were neglected when it remembers the things that entered its line of sight afterward, again with a particular orientation, or when someone reminded it. The perception of existence and unity, too, is a perception that reason conceived both in and of itself and in every object it perceived, and that it turns into awareness once it was oriented to or indicated by it. For this reason, Islamic thinkers suppose that the perception of existence and unity is a priori, but not intuitional in the sense defined above by al-Jurjānī. The first of 
the seven types of categorical premises viz. a priori propositions are explained in Sharh al-Mawāqif thus:

These are the premises that the soul cannot lack after conceiving of both parts and thinking about the relation in between. Some of them are evident for all people due to the manifest conception of the parties, while some others are latent due to the obscurity in their conception. That part too is not latent for sharp minds that have penetrated conceptions. ${ }^{21}$

What it means is this: It is not necessary for reason to perceive each and every object in order to judge the whole or to think of existence and unity as the existence and unity of the whole, because the idea of totality cannot be deduced. Such an argument, when leveled against metaphysics, is unjust and improper inasmuch as it expects reason not to reason. But reason, ipso facto, uncovers the possibilities of universality for the meaning it conceived. True, reason needs mediators to objects in order to ascertain the substantial subjects of the concept, but not any inference or method for generality or universality. For this reason, al-Juwayni distinguishes knowing the part from the whole, thereby implying that judgments concerning the whole are based on the evidence of reason whereas judgments concerning parts or single external beings require methods appropriate to the nature of those beings. He therefore emphasizes the certainty of general knowledge (al-umūr al-jumlìya) concerning the whole. ${ }^{22}$ Thus, there has to be either an impropriety of concepts and propositions for the use of any inference or method, or the manifest inferences and methods in case they are proper must be traceable, when passing from the particular to the universal. Moreover, the expression of an initially nominal value for the transition from the part to the whole in the meanings of the first category, or the thought of a homonymy in Islamic thinkers' parlance, originate only from the insufficient analysis of a priori and intuitional comprehension. This is because metaphysical thought follows, in greater part, the conviction that the naivete and depth are contained together within the everyday experience of existence. For this reason, the comprehension of existence and unity comprises the main support of the experiences of all human individuals. That is, these perceptions do not require objectification as do other experiences that are circumscribed by individuals or human groups.

21 al-Jurjānī, Sharh al-Mawãqif, 1: 422. The underlined section is by al-Ījī.

22 Cf. al-Juwaynī, Al-Burhān fì Ușūl al-Fiqh, ed. 'Abd al-'Ażīm Ildib (Doha: al-Jāmi'at al-Qatar, 1978), 142. For a detailed analysis of al-Juwaynīs view, see. Ömer Türker, "Bir Tümdengelim Olarak Şâhitle Gâibe İstidlâl Yöntemi ve Cüveynî’nin Bu Yönteme Yönelttiği Eleştiriler,” İslâm Araştırmaları Dergisi 18 (2007): $1-25$. 
At this point, the need for admonition and objectification may breed confusion. But there is a certain and non-negligible difference between these two conditions. Whereas admonition signifies a state contained manifestly in the experiences of all human individuals, but one that is unrecognized due to a sort of mental indolence, objectification signifies a state in which common experience is non-evident and the transmission to the perceiving subject's experience needs a special effort. Thus awareness has to be especially emphasized, for experiences are lived as a totality. Even more, they are articulated by making universal enunciations. Nonetheless, reason may fall back on conceiving the absoluteness of existence and thus may need admonition (tanbih) for this reason. Contextually, the legitimacy of metaphysical knowledge depends on neither the recurrence of the awareness nor its initial objectivity, but on the necessary formation of the knowledge of existence and the objective expressivity of the primarily and intuitionally conceived necessity's actualization in common experience. In other words, the supports of this objectivity, one of the principles of the aforementioned comprehension as held in common by individual human beings, were already gifted to the perceiving subjects. Besides, when reason arrives at the concept of general existence, this general existence still appears as one in the sense of external presence, that is, it informs the external world being receptacle to things that are. To distinguish between the external presence of an object and of all objects that were and can be taken, one needs to distinguish between existence in the sense of external presence and being as qualified by this existence. Thus the meaning in the infinitive sense and the object conveying that meaning are distinguished from each other. The crucial threshold at this stage of analysis is that both sides of the aforementioned distinction make it possible for some meanings to be included into the steps of analysis. What is included within the analysis with respect to general existence, as Quṭb al-Dìn alRàzì notes in his explanation of the presence of universal concepts in the mind, ${ }^{23}$ is the differentiation of the mental image and the thing of which it was the image. The concept of existence that was realized as a quality or relation in the mind serves the function of a mirror to the comprehension of a meaning that was actualized and realized with the external objects. Islamic theologians and philosophers of the later period intended this meaning when they said that the concept of existence is the secondary intelligible, ${ }^{24}$ because existence in this sense, considering the exterior's being the receptacle for objects, is a meaning that was comprehended by reason and nafī, "Sharḥ Risāla Tahqīq al-Kullīyyāt," in Risāla fì Taḥqĩq al-Kullīyyāt: Tümeller Risalesi ve Şerhleri, ed. and Turkish trans. by Ömer Türker (İstanbul: Türkiye Yazma Eserler Kurumu Başkanlığı, 2013), 58-64. 
was not present as the essence of species of any object. In addition, the meaning said to be the secondary intelligible can evolve into a common meaning that qualifies all objects and materializes as each being itself, for it is not being thought of in relation to a certain object. That is, it is possible to move from existence, in the sense of being external, to existence in the sense of external being. However, the transition to the external being changes character once reason arrives at the distinction of existence and being. What makes the difference is reason's comprehension of the necessity of the meaning of existence, for that meaning, considered to be abstracted from a certain external being, inevitably makes the relation to non-existence impossible.

The most conspicuous example of this in the history of metaphysical thought is the dichotomies of existence-essence and necessary-contingent employed by Avicenna, who conceived of the transition from part to whole in intuitional evidence. Just like he suggested, reason distinguishes existence and being first, when it comprehends the meaning of "being qua being," having arrived at the universality of the predications of existence and unity. In this context, in the beginning of his Sharḥ al-Ishārāt Fakhr al-Dīn al-Rāzī reckons that Avicenna, in contradistinction to his predecessors, constructed metaphysics independent of physics by focusing on the meaning of existence itself. ${ }^{25}$ Whereas Nașīr al-Dīn Tūsī objected to al-Rāzì's observation with the superficiality of having conceived the issue only on logical grounds, ${ }^{26}$ the differentiation of existence and being with such a sharp intuition is attested to in Avicenna's philosophy. ${ }^{27}$ Verily, reason evidently conceives the probable relations of each single object, or of essences qualified by existence in Avicennan parlance, to existence, once we move from the existence of each single object to general existence. That is, the realization of the meaning of existence as a certain being would be either necessary or contingent. However, "being qua being" can be subject to the predication of "either necessary or contingent" only when we connect existence with essence, that is, when we take into account the external being that is a particular realization of it. On the other hand, we can only qualify "being qua being" with necessity insofar as we subject it to a proposition, because it is impossible to include non-existence in the definition or concept of existence and existence ipso facto excludes non-existence. Yet again, identifying the meaning of existence with its particular realization is impossible, insofar as there is the possibility for the relation of being to non-existence. Therefore, the objects that are said to be beings are things that exclude existence and non-existence in their definitions. 1383/1963), 1:6. 
From this point of view, the pronouncement of Ibn al-'Arabī's followers that the meaning of existence is a natural universal, ${ }^{28}$ is the result of an elaborate analysis of Avicenna's intuitional comprehension and requires one to conceive a particular being necessarily as a state of existence. Indeed, criticizing the principle that causes do not affect the essence but rather its existence, Fakhr al-Dīn al-Rāzī argues that one would conclude that existence would emanate solely from God and that multiplicity would occur via the multiplication of contingents. However, Avicenna did not arrive at this conclusion. ${ }^{29}$ As supposed by Avicenna, this certainly necessitates the equal relation of each being per se to existence and non-existence. But of greater importance, when the utterance of being is employed for objects that have an independent and distinct external existence, one can potentially apply Abū Hāshim al-Jubbā'ī view of states unconditioned by existence and non-existence not only to a number of attributes, but also to beings that can be conceived of as a particular realization of existence. This is because the meaning of existence, as an all-encompassing meaning, imposes the conception of all realizations as a state of itself. Thus the concept of being reconciles continuity and change because being, while expressing continuity in relation to the universal meaning of existence that bears it, attests to mutability and transience as a realization of that meaning. The continuity of being that cannot be classed under everyday occurrence does not contradict the aforementioned transience, because the predication of existence and unity, while exhibiting necessity concerning the whole, indicates contingency concerning each single object.

\section{Is Existence a Sophisticated Concept?}

We should take on a harder question at this stage of the discussion. Once we abstract the meaning of existence from each single object, can we reach a meaning that is beyond its meaning of the exterior being a receptacle for something? We can specify the question further: Once we think of existence as a natural universal, all of the meanings that we would attribute to it are the meanings of each single object. Leaving aside their properties, apparently what remains is a meaning called "existence devoid of content." If that is so, we do not even make a predication when we say a particular thing exists, besides the realization of a universal and encompassing meaning of that being. As a matter of fact, this question recalls a 
formidable problem that determined the direction of the studies on existence and caused many philosophers to view the concept of existence as one of secondary importance. As a response, we shall start with the analysis of what is purported when we say that "something exists."

In the first place, when we say "the human exists," for instance, roughly we mean that it has a being aside from being a subject. Insofar as we think of the meaning of humanness and the being of the human being to be one and the same thing, we say that the predication of existence is no supplement to its meaning. According to this view, it is also possible to regard the predication of existence as a refutation: When we say "the human exists," we deny its non-existence or refute that it does not have a being external to us. Certainly, this holds as long as the predication of existence is identical with the meaning of the object. If nothing changes concerning the totality of meanings attributed to the object in the predication of existence or refutation of it, it is certain that something changes concerning the external presence of these meanings. For instance, saying "the human is human" and "the human exists" do not express the same meaning. Both sentences would have meant the same thing if the predication of existence had not imparted a supplementary meaning to the object. However, the utterance "the human is human" does not signify any meaning concerning its being, for it only expresses the thing itself, whereas the utterance "the human exists" conveys a meaning concerning the human's being. Certainly, a philosopher of the persuasion that existence is not a predication would argue that it was definitely so logically speaking, for what was called human in its exterior and its existence was one and the same thing. But the lack of any distinction between the humanness in its exterior and its existence does not show that it was its existence per se as well. This is because we can think of the meaning of humanness without contradiction, both when we attribute existence to his meaning and when we do not. It becomes clearer when we apply this analysis to an individual. For instance, we can think of the existence and non-existence of a human individual, say Ali. To someone who does not know of Ali's existence, we should also mention that he existed after explaining who Ali was. In such cases, the predication of existence is a predicate that was not contained within the meaning of the object, and that gave an unknown meaning when we knew the object's name and definition. Then what is the thing that was not contained within the object's meaning and was expressed with the predication of existence?

When we say that an object exists, we say that it is necessary in one way or another. Therefore, supplementing the predication of existence to the object is a necessity. As Avicenna suggests, an object is contingent if we can presume its existence or non-existence without undergoing any contradiction when we think 
of it. Avicenna defines contingency as a thing's equidistance in relation to existence and non-existence. When we predicate the meaning of existence to a contingent, we attribute a sort of necessity to it. ${ }^{30}$ Verily, necessity prima facie qualifies a thing's relation to both existence and non-existence and, for example, employs the phrases "the necessity of existence" and "the necessity of non-existence." But the necessity attributed to non-existence is a necessity that was conceived in comparison with existence and thus does not impute any extension, for it was in the necessity of existence. That is, whereas the necessity of existence is a meaning that can be thought of and comprehended, the necessity of non-existence comprises only the negation of that necessity. Therefore necessity is a meaning related to existence. In this condition, existence itself is identical with necessity and thus including contingency in its meaning is impossible, for the presence of an aspect of nonexistence in the meaning of existence is ipso facto impossible. In fact, such an idea is a self-contradiction of reason. For this reason, being qua being indicates only necessity. What needs attention here is the non-relationality of existence that was identical with necessity in any way. That is, existence in this sense is not the relation of the meanings externally actualized to the exterior, but rather a meaning that was actualized in the exterior. This meaning is the necessity that makes all meanings, which we can refer to "other than existence," exist by qualifying them with itself. Therefore, the necessity of existence corresponds to the first past of the necessity that Avicenna stated: "It is said qua absolute existence without any condition." In other words, it cannot be negated or taken on the contrary. Since it is the contradiction and negation of necessity, the non-existence of impossibility is qualified by necessity as well. That is, the former is pronounced in terms of absolute existence, whereas the latter is pronounced in terms of absolute non-existence. Hence, all the meanings attributed to this necessity are contingent in the sense of being imputable to existence. The relation between the necessity and the contingent meanings is what Avicenna calls "general existence". That is, when any contingent meaning can be imputed to existence, we say that it exists. Since there can be no relation with a thing in the absence of that very thing's existence, existence in this sense supplements the contingent. Thus the imputation to existence inevitably wins a new status for the contingent meaning. This status is the necessity that the contingent possessed and graded further on a par with the gradations of necessity. Hence, Peripatetic logicians enumerated the necessity in this part in five points. In Kitāb al-Shifä'Burhān, Avicenna summarizes the five points in the following manner: 
Or, necessity is pronounced in terms of the existence of any predication or its nonexistence - which is the negation of the predication. This section is of five sorts. Accordingly it is said: [i] Either negation and affirmation are continuous from the primal beginning to the ultimate end. For example, like our diction: "The Creator is one and is not a body." [ii] Or, negation and affirmation are not absolutely continuous but, on the contrary, continue as the individual subject continues to be. An example of this is this phrase: "All humans are necessarily animate," that is, being animate is imputed, insofar as the individual being of all humans and everything qualified by humanness - that is the subject - not continuously, because every human being suffers corruption and does not keep on being qualified by being animate. [iii] Or, it continues insofar as the individual is qualified with the meaning that was subjected with it, not for the duration of its existence. An example of this is: All white necessarily has a color that the eye discerned; however, it is neither everlasting nor does it continue to be so long as the one qualified by whiteness continues to exist. For some individuals qualified by whiteness, although they continue to exist, both this attribute and its requisite - to have a color discerned by the eye - are forsaken. On the contrary, [the attribution] continues to be insofar as the individual is qualified by being white, because it certainly is qualified as an individual discerned by the eye. [iv] Or, its necessity is conditioned to continue as long as the predication exists. [...] Being among the necessaries, the matter of this mode is contingent for all subjects at all times. By the same token, it is distinguished from other sorts. [v] Or, necessity is not conditional to subject and predication, but to time that has necessarily happened. Our words are an example of it: "The moon is necessarily eclipsed," that is, it eclipses at a time. ${ }^{31}$

The sections of necessity mentioned here are the subsections of the third section of necessity and follow those mentioned above: absolute existence and impossibility. Therefore, all of the sections of necessity expressed in the passage involve predications devoid of absolute necessities. Thus the passage, being a summary of the Aristotelian tradition's explanation of necessity, indicates an important meaning concerning the essence contributed by the meaning of existence. Accordingly, no predicate, whether it is the fundamental element or the temporary or permanent attribute, is necessary as long as it can be regarded as the predicate. Whether it was predicated to its subject in perpetuity or at a certain time interval, no predicate abstracted from the meaning of existence and regarded as the predicate per se exhibits necessity in and of itself. That is, fundamental or not, no attribute conceived of as a meaning in itself ever exhibits necessity since existence is not integral to its definition. Moreover, in case a subject consists of many meanings, its unity as a meaning is conditional upon the assembly of its parts. In that case, the predication of the parts to the subject is only necessary with respect to its 
relation with the subject. However, this is a relative, not an absolute, necessity, and if there is no continuity to the meaning of existence necessary in and of itself, then neither the assembly of the parts nor the thematic unity would have any necessity. In fact, this state points to a suggestive conclusion: Insofar as the necessity of the meaning of existence is neglected, in the final analysis the extension of the objects are deprived of the essence of the whole and turn into slight meanings. Neither the substances upon which we conferred existence per se could really exist in and of themselves, nor could the attributes that we speak of existing by relating them to substances really exist by being related to any substance. All of these distinctions appear to be labels based on the functions of meanings that complement each other in order to exist in the exterior, for once devoid of any necessity due the meaning of existence, the hierarchical structuring of meanings has no significance with respect to an object's being. That is, the relational necessity dictated by the hierarchical structuring of meanings, like partaking of an object's fundament or being a permanent or temporary attribute of it, is realized only when the meanings are fed into the meaning of existence.

This point shows us that the existence of necessity per se is the cause of relational necessities. But its causation, like the Avicennan metaphysical cause, does not mekan being another cause that gives existence than the own existence of the meaning of existence. Avicenna, and the Islamic philosophers and theologians who came later, employ the word existences (wujūdat) for those parts that the contingent beings partake of the ultimate principle of existence. ${ }^{32}$ That is, they argue for a plural form of the existence in infinitive. Yet there can be no other existence than existence itself, lest it be presumed to give something else from itself to another thing. In this sense, the division of existence into physics and metaphysics, or into rational and corporeal, is misguided because existence itself is the most general meaning and the perception of existence with awareness can only be achieved by reason. If the distinctions of physics-metaphysics and corporealrational are maintained, there can be a statement with import in the context of the simplicity and complexity of beings. Pertinently, all beings serving their own functions show us that each being is a kind of percept of existence, for each object is situated within a web of relations. Whether we call it perception or something else, it is in a state of continuous attention toward things with which it came into contact. But the conscious perception of existence is a rational perception, that is, the perception of perception is rational. It not only shows us that the supreme perception of existence is rational perception, but also that both the self-necessity 
of existence, which was slighted while turning contingent meanings into an external being each, is rational, and that the existence actualized in each being is rational. In this sense, the conception of the totality of existence, which was particularized in a thing, qua existence is rational. Moreover, by means of lending necessity to the meaning with which it came into contact, the concept of existence is not a vacant meaning that was occupied with the objects that it was referred to; rather, it was an essential meaning that makes beings exist, discloses their internal capacities, and revitalizes dull meanings. Hence, Islamic philosophers supposed that the ultimate principle, that the being qua being was reified, is the Intellect, the Intellecting, and the Intelligible. This statement is quite significant for expressing the particularity of existence on the one hand, and the fundamental quality of the most perfect form of existence, namely, not slighted by contingency, on the other, for existence has to be a rational meaning reified in the exterior, insofar as exhibiting necessity. But the being of existence is not in the manner of the exterior being receptacle to it, but its constitution of the exterior at the same time. In other words, existence being the absolute necessity itself is prima facie contradictorily both the exterior that was receptacle to the external beings, and the exterior itself for being receptacle, since it lends necessity to the external beings, that is, the beings exist with it. Hence, existence exhibits an absolute simplicity in addition to necessity, wherefore there is nothing having such simplicity except for the existence. That is, necessity's reification and becoming a particular, just like al-Fārābī and Avicenna suggested, requires its presence in a state of absolute simplicity. Accordingly, existence is a necessary, simple, encompassing meaning as well as a perceiving subject at the same time, for it is the ultimate particular by which all objects are perceived.

In fact, conceptualizing the meaning of existence as a perceiving subject is the threshold for passing from ontology to theology. The metaphysician philosophers of the ancient world justified the transition to theology by the immaterial presence of the meaning of existence in the exterior. In a thought system that accommodates the theory of Intellects, a justification based on immaterial meaning, however questionable, may serve its purpose. Nevertheless, as Fakhr al-Dīn al-Rāzī states, when we think of an immaterial meaning's existence in the exterior, we still doubt its being a perceiving subject. That is, the reasoning that justifies the transition from meaning to subject is not fool-proof because it is a derivative of a number of unjustified premises. ${ }^{33}$ In my opinion, this transition is demonstrated not deductively, but via a syllogism that is similar to analogy but not analogical. The 
similar aspect is this: When we notice the qualities of knowing and awareness that it knows in a human subject and, at the same time, that the human is not a necessary existence, we comprehend that the simple state of the necessity of existence is a knowing subject. But having rendered this conception into a deductive form, it is misleading to add human consciousness to the analysis' transitory step from ontology to theology with respect to syllogistics, for a syllogism that seeks to establish the relation between human consciousness and absolute existence lacks a middle term:

a. The human is a perceiving subject.

b. Absolute existence...

c. Absolute existence is a perceiving subject.

Obviously, absolute existence has to be within the scope of the human in order for "c" to be the conclusion of premises "a" and "b." The falsity of this needs no discussion. For this reason, subsequent theological and philosophical traditions held that the question of why contingent and actual beings exist cannot be answered unless an ultimate knowing subject is presumed. This is because if something is contingent and actual, and since it is impossible to attribute existence independent from an agent to such a thing, it would not be qualified by existence-in-itself. Theologians asserted that the agent was a perceiving subject on the grounds that the world necessitated a mighty, wise, and knowing agent. They then stated that this agent had a will by the actuality of the world. Philosophers like al-Fārābī and Avicenna, however, argued that this ancient or necessary existence could not be physical or corporeal, and that every being that is not such is a perceiving subject. Thus they demonstrated that the thing that exists in the exterior as a reason or a meaning is a knowing subject by instituting a principle, through which they explained this principle, and then turned the question of which external beings existed rationally into a subject of investigation. All of these demonstrations, which varied a great deal among themselves, are based on the transcendence of the ultimate principle that makes existence and its external being distinct from all other beings. That is why it necessarily requires dichotomies like ancient-modern and agent-action. The first term of these dichotomies is always beyond human experience. Therefore, however strong a proof based on these dichotomies might be, it leaves an insurmountable gap in terms of satisfying the mind, which is paved with mines of doubt, by transforming all proofs into analogies. However, the proposition that absolute existence is a perceiving subject is a necessity imposed by the features of perception belonging to those objects we recognize as existing. Verily, if the simple and encompassing meaning of existence that granted necessity to all beings does not possess the quality of knowing in itself and the awareness that it knows, none of the beings would have 
it, because this quality is not a thing that exists as a result of any being's imperfect signification of the meaning of necessity, which would impart a state of depravity. On the contrary, a human being as a subject that knows and becomes aware that it knows is entitled to think and talk on the meaning of existence by the merit of this quality, and attempts to comprehend the relational order among beings. For this reason, that the meaning of existence is a knowing subject besides its necessity and simplicity, is a meaning that we conceived when we perceived the sphere of beings that this meaning itself made to exist including ourselves.

All other propositions of the theological branch of metaphysics emerge based on this conception. However, the conclusions of this state are not restricted to the theological branch, for they extend to both ontology and theology. Therefore, it allows tension as well as a possibility for resolution in establishing the relation between the constancy of the meaning of existence as an ultimate principle and the continuous movement of the objects that be, and the relation between the totality of the meaning of existence as a knowing subject and the fragmentariness of objects. That is why the most significant problem for both the theological and philosophical sections of the disciplines claiming universality is the dichotomy of unity-multiplicity. Thus all main titles of the books on metaphysics, theology, and mysticism are subheadings of the relation of unity-multiplicity. Thus the question to be posed in the context of the necessity of existence and the contingency of beings is the quality of the relation between the subject of existence, which is a comprehensive, necessary, simple, and knowing meaning, and the objects that came into being due to its necessity. The answer to this question, which problematizes the relation of beings with the meaning of existence as the object of knowledge and being, lies in the comprisal of infinite meanings and possibilities within the necessity of the meaning of existence as a knowing subject. What is meant by necessity's comprisal of infinite possibilities is not that the meaning of existence, in a manner that would contradict pure necessity, becomes the locus of an external possibility. This is because possibility, as the theologians supposed, ${ }^{34}$ means the referral of the absoluteness of existence, as a rational relation that expresses the qualification of being by existence, to any object. In this context, the meaning of existence has a relation of two sides but one form with possible objects. The first side of the relation refers to knowledge. Existence as a knowing subject necessarily comprises all meanings that were and can be found in its universality. It is the necessary condition of the existence of any possible object, for the possible verily cannot be, lest it was known by the existence as the universal subject. As a matter 
of fact, the relation of everything formed by the knowing subject to the knowing subject is as such. For instance, the relation of artificial objects to the human subject is entirely so. Insofar as the human mind does not know the existence of hammer, car, computer, family, and state, none of them can be. These objects, on the condition that they are not present in human knowledge, are non-existent not only in the sense that they would not have existence in the external world, but also that their existence in the exterior would be cancelled and thus they would revert to their constituting elements.

Just like that, it is impossible for possible objects that gained existence in the exterior to exist by being qualified with necessity in any plain, unless they are in the knowledge of the universal subject. Indeed, all beings exist in the necessity of existence as "epistemic relations." There is a continuity and constancy in this knowledge appropriate to the essence of necessity and universality. What mobilizes the constancy in knowledge and transforms the contingent meaning into a real object is the movement of agency (the subject's becoming) belonging to the meaning of existence, for necessity, as the primary attribute that qualifies existence, moderates not only the continuity but also the agency of existence. That is, inasmuch as necessity expresses spontaneity, inexhaustibility, and the universality of existence, necessity accordingly expresses its bearing infinite meanings and its perpetual release (istirsāl), in al-Juwaynī's phraseology or what Ibn al-'Arabì dubs manifestation (tajalli), in these meanings too. ${ }^{35}$ In fact, I employ the words release or manifestation, both apparently metaphorical, to mean the subjectification and reification of epistemic relations by the meaning of existence. The employment of phrases purporting subjectification and reification in order to explain the becoming of an epistemic relation appears to be a circular argument. It is also possible to articulate the changes in the states of absolute existence with the words creation, appearance, or issuance by altering their traditional semantic fields in order to solve the problem of circularity. But what I meant to say herein is the presence of the infinite meanings that the necessity of absolute existence comprised as an epistemic relation, yet again with the conscious orientation of that existence in the receptacle of existence. The inexhaustibility of necessity and the meaning of existence also bring out the infinity of possible meanings. Therefore, inasmuch as there cannot be an absolute existence without consciousness, there cannot be an absolute existence without will.

35 On this point, see İbn al-'Arabī, al-Futūhāt al-Makkiyya, ed. Aḥmad Shams al-Dīn (Beirut: Dār al-Kutub al-'Ilmiyya), I:246-250. For an analysis regarding being and existence see Ekrem Demirli, "Varlik Olmak Bakımından Varlık İfadesinin Sûfîlerce Yeniden Yorumlanması ve Bu Yorumun Metafizik Sonuçları." İslâm Araştırmaları Dergisi 18 (2007): 27-47. 
Islamic philosophers and the theologian al-Nazzām argued for the impossibility of the will for absolute existence. The mystics of the "unity of being" bend, however, argued for the impossibility of considering the will with respect to the everchanging contingent and absolute existence having a single relation to all objects. What lies at the origin of these thoughts is the theory of forces, which supposes the irrelevance of the concept of the will unless there is a process between thought and action. Thus the philosophers argued that neither God nor the incorporeal Intellects have a will. Verily, this view is accurate in proposing that the will has a condition pertinent to contingency. Yet despite being an analogical view of the relation of absolute existence with contingency, it appears as a deductive fallacy. Despite the acute differences among the aforementioned thinkers, there is a single origin to the meaning of existence according to all them: absolute existence. It requires, as notified by the theologians, the comprisal of the possibilities of beings as rational relations, in the necessity of absolute existence, with the attribute of infinity that was exhibited by that necessity. That is, the supposition that the meaning of existence, as the origin of contingent objects, is a consciousness devoid of any will comes to mean that it is a consciousness without the attribute of agency. This cannot be reconciled with the multiplicity of beings and their perpetual change. For this reason, the aforementioned release or manifestation that reveals the conscious and voluntary preference of existence expresses the constancy of epistemic relation vis-à-vis the meaning of the contingent as well as the movement of agency vis-àvis the being of the contingent. This release or manifestation, as the philosophers and the theologians supposed, qualifies the contingent meanings with the meaning of existence; however, contrary to their supposition, it does not give an existence other than the universal existence to the contingent meanings, for doing so would have amounted to changing the necessary meaning of existence into contingent. However, contingency consists of the unnecessariness of the relation of the contingent meaning and the existence lent to it. Existence is what it is in itself. It does not increase, decrease, or change; it does not cease to exist while it exists; and it does not exist while it is non-existent. All of these are the qualities of beings that are qualified with existence by means of the revelation of the meaning of existence. Therefore, what is subject to the agency of the meaning of existence is not existence per se, but rather an object to be qualified with existence. As al-Jurjāni suggested, the agent that lends existence does not render existence as existence, but rather renders it existent by attributing existence to the contingent. ${ }^{36}$ The existence that is attributed to the contingent is the necessary and general existence itself. Thus for the contingent, being is the change of rational relation into external relation. But there is no exterior except for existence. 


\section{As Conclusion: A Quick Glance at the Problem of Truth}

At the end of the discussion above concerning the first assumption of the criticisms of metaphysics, we noted that the question of truth and correspondence could only be resolved by analyzing the formative process of the meaning of existence and other metaphysical concepts and propositions in our mind. Now we can pose the question: How would we know that all of these analyses are true or not? The answer to this question becomes clearer with attention to two significant thresholds of the formation of the knowledge of existence in human being. First, that the knowledge and the awareness of the human being concerning its own existence is a priori. Metaphysical thought depends on this perception, which does not require evidence in any way, because when we conceive of the relation between the consciousness and knowledge of existence and being human, we comprehend that the human being is ipso facto a metaphysical being. When we set the human being's perception of its own existence in brackets, the human being cease to be human. Therefore, this perception is equivalent to being human, and the sole support of reason against sophism. The second significant threshold is that the human being's knowledge of its own existence is a succinct perception that was elaborated upon "by means of" the being's perception of the objects outside itself. In this context, the consciousness of "I" is evident to all, as long as it is perceived as a succinct perception. That the human experience of existence in its unity is the elaboration of the said succinct perception, although this is not equally evident, would be conceived of when the individuals' experience of existence or states of being were analyzed. The key point in these two conceptions is the non-temporality of the self-consciousness as a type of the consciousness of existence, although its expression is temporal. This condition connects the self-consciousness intuitionally with absolute existence on the one hand, and with the phenomenal world that emerges through time on the other. But both aspects are contained within the same experience of existence, and each human experience is extemporal vis-à-vis existence and temporal vis-àvis being. In other words, if we define the concept of time as "the quantity of the realizations of the meaning of existence," the realization of human experiences is certainly temporal, whereas the perpetual modes of the necessity of the meaning of existence by means of these realizations are non-temporal.

While the Sophists' criticisms argue the unreliability of all sorts of perception at the basis of half of the criticisms against metaphysics, the other half is convinced that human intellect is an "instrument" that only serves the function of perception and is therefore filled with sensations. However, reason is a self-contained form and meaning concerning absolute existence and its secondary meanings. Other faculties fundamentally serve the function of "indication" and "means" to 
elaboration and universalization of this content. Hence, metaphysical knowledge basically depends not on the causal relation between objects, but on the relation of universality-particularity and the rational necessities between meanings, as al-Juwaynī supposed. ${ }^{37}$ No doubt, reason becomes entirely instrumental once it is detached from absolute existence. Therefore the source of knowledge is neither the instrumentalizing reason nor the senses, which are its gateways to the external world, for knowledge only reveals itself in relation to reason by the absoluteness of existence. Thus the origin of knowledge is existence itself, and all beings that we perceive are knowable by us to the extent that they could be perceived as a realization of absolute existence. Knowledge, in this context, is not the concepts and propositions in our mind, but rather being human itself. There is probably no other concept in the history of metaphysical thought, other than the mystics' concept of "actualization," that perfectly expresses this comprehension, for no perceiving subject could know what it is not. For this reason, the analyses from the beginning of the article are true and adequate to the extent that they are an explication of human quiddity, because they consist solely of the elaboration of a succinct perception that is evident. There is no reason to occupy oneself with proving the evident by the theoretical. This is what is meant by saying that the conception of being qua being could be reached through an analysis of the human being's everyday experience. Thus, an extra demonstration for the aforementioned elaboration is a lapse into a never-ending whirlpool of argumentation. If there is a path in a human being's evidently felt everyday experience to a conception of absolute existence, metaphysics is not only legitimate but also necessary. If there is no such path, then no demonstration can convince us that we are "human."

Subsequently, I discussed the objections to the possibility of metaphysics by turning them into propositions that are as comprehensive as possible. I did not have the opportunity to comment in detail on the criticisms and objections, articulated especially by Kant and those who came later, against the fundamental views I defended, among them the impossibility of reason's producing false percepts - not false concepts and propositions -, that existence is a predication, and the extratemporality of self-perception. It is obvious that any defense of metaphysics requires a closer engagement with these criticisms. However, the space and format of this article could not accommodate such detail. If time permits, I hope both to elaborate and expand upon the views I put forth herein and to take on the contemporary criticisms of metaphysics in detail at a later date. 


\section{Bibliography}

Audi, Robert. Epistemology. New York: Routledge, 2005.

Ayer, Alfred J. Language, Truth, and Logic. New York: Dover Publications, 1946.

al-Baghdādī, Abū al-Barakāt. Kitāb al-Mu'tabar. Ed. Yūsuf Mahmūd. Qatar: Dār al-Ḥikmah, 2012.

Demirli, Ekrem. "Varlık Olmak Bakımından Varlık İfadesinin Sûfîlerce Yeniden Yorumlanması ve Bu Yorumun Metafizik Sonuçları.” İslâm Araştırmaları Dergisi 18 (2007): 27-47.

Gürsoy, Adnan. “İbn Sînâ’nın Sezgi Teorisi.” Unpublished PhD diss., Ankara University, 2015.

Ibn Sīnā, Al-Ishārāt wa al-Tanbīhāt. Ed. J.Forget. Leiden: E.J. Brill, 1892

Ibn Sīnā. Al-Shifā': Kitāb al-Nafs. Eds. Jūrj Qanawātī and Sa'ìd Zāyid. Cairo: al-Hay’a al-Mișriyya al-'Āmma li al-Kitāb, 1975.

Ibn Sīnā. Al-Ta'līqāt. Ed. 'Abd al-Rahmān Badawī. Qom: Maktabat al-I'lām al-Islāmī, 1984.

Ibn Sīnā, al-Shifä’: al-Burhān. ed. Abu al-Alā Afīîi. Cairo: al-Matba'a al-Amīrī bi al-Qāhira, 1956.

Ibn Sīnā. al-Shifä’: al-İlāhiyyāt. ed. and trans. Michael E. Marmura. Utah: Brigham Young University Press, 2005.

Ibn al-'Arabī, al-Futūhāàt al-Makkiyya. ed. Ahmad Shams al-Dīn. Beirut: Dār al-Kutub al-'̇̇lmiyya.

al-Jāhịiz, Abū 'Uthmān 'Amr ibn Bahr. "Al-Masā'il wa al-Jawābāt fĩ al-Ma'rifah.” In Rasẩil al-Jāhiz, IV, ed. 'Abd alSalām Muhammad Hārūn, 47-65. Cairo: Maktabat al-Khānjī, 1979.

al-Jāmī, 'Abd al-Rahmān. Al-Durrat al-Fākhirah fī Taḥīq Madhhab al-§ūfiyya wa al-Mutakallimīn wa al-Hukamä' alMutaqaddimīn. Eds. Nicholas Heer and 'Alī Mūsawī Bahbahānī. Tehran: Mū'assasah-i Mutāla’āt-i Islāmī Dānishgāh-i McGill Shu'bah-i Tahrān, 1980.

al-Jurjānī, Sayyid Sharīf. Al-Ta'rïfät. İstanbul: Es‘ad Efendi Matba'ası, 1300/1883.

al-Jurjānī, Sayyid Sharīf. Sharh al-Mawāqif: Mevâkıf Şerhi. ed. and Turkish trans. by Ömer Türker. İstanbul: Türkiye Yazma Eserler Kurumu Başkanlığı, 2015.

al-Juwaynī. Al-Burhān fï Ușūl al-Fiqh. Ed. 'Abd al- 'Aẓìm Ildib. Doha: al-Jāmi'at al-Qatar, 1978.

Kant, Immanuel. Critique of Pure Reason. Trans. Paul Guyer and Allen Wood. Cambridge: Cambridge University Press, 1998.

Kant, Immanuel. Prolegomena to Any Future Metaphysics. Trans. Gary Hatfield. Cambridge: Cambridge University Press, 2004.

Molla Ḥanafĩ. "Sharḥ Risāla Taḥqīq al-Kulliyyāt," in Risāla fì Tahquĩq al-Kulliyyāt: Tümeller Risalesi ve Şerhleri. ed. and Turkish trans. by Ömer Türker. İstanbul: Türkiye Yazma Eserler Kurumu Başkanlığı, 2013.

al-Qūnawī, șadr al-Dīn. al-Murāsalāt bayna șadr al-Dīn al-Qūnawī wa Nașir al-Dīn al-Tūsī. ed. Gudrun Schubert. Beirut : Franz Steiner Verlag, 1995/1416.

al-Qūnawī, Șadr al-Dīn. al-Nușūs fì Tahquĩq al-Ṭavr al-Makhșūṣ. ed. Ibrāhīm Muhammad Yāsīn. Cairo: Menshe'etu alMaārif, 2003.

al-Rāzī, Fakhr al-Dīn. al-Mabāhịth al-Mashriqiyya. Eds. Muhammad Mu'tașim Billāh al-Baghdādī. Beirut: Dār al-Kitāb al-'Arabī, 1990.

——al-Mațālib al-'Āliya. Ed. Aḥmad Hijāzī al-Saqqā. Beirut: Dār al-Kitāb al-'Arabī, 1987.

. Muhașsal Afkär al-Mutaqaddimīn wa al-Muta'akhkhirīn min al-'Ulamā wa al-Hukamā wa al-Mutakalliminn. Ed.

Tāhā 'Abd al-Ra'ūf. Cairo: Maktabat al-Kulliyyāt al-Azhariyyah, n.d.

Sharh al-Ishārāt wa al-Tanbīhāt. Istanbul: Dār al-Tibā'at al-'Āmirah, 1290/1873.

Sharḥ al-Ishārāt. Ed. 'Alī Riḍā Najafzādah. Tehran: Anjuman-i Āsār va Mafākhir-i Farhangī, 1383/1963.

al-Rāzī, Quṭb al-Dīn. "Risāla fĩ Tahquīq al-Kulliyyāt" in Risāla fì Tahquīq al-Kulliyyāt: Tümeller Risalesi ve Şerhleri. ed. and Turkish trans. Ömer Türker. İstanbul: Türkiye Yazma Eserler Kurumu Başkanlığı, 2013.

Ṭūsī, Nașīr al-Dīn. Sharḥ al-Ishārāt. Ed. Sulaymān Dunyā. Cairo: Dār al-Maāāif, 1960.

Türker, Ömer. "Bir Tümdengelim Olarak Şâhitle Gâibe İstidlâl Yöntemi ve Cüveynînin Bu Yönteme Yönelttiği Eleştiriler." İslâm Araştırmaları Dergisi 18 (2007): 1-25.

Türker, Ömer. "Eş‘arî Kelâmının Kırılma Noktası: Cüveynînnin Yöntem Eleștirileri." İslâm Araştırmaları Dergisi 19 (2008): 1-23.

Türker, Ömer. İbn Sînâ Felsefesinde Metafizik Bilginin İmkânı Sorunu. İstanbul: İSAM Yayınları, 2010.

Üçer, İbrahim Halil. İbn Sînâ Felsefesinde Suret, Cevher ve Varlık. İstanbul: Klasik Yayınları (forthcoming title). 